\section{Case Reports in Gastroenterology}

Case Rep Gastroenterol 2021;15:400-407

DOI: 10.1159/000514395

Published online: March 18, 2021

(C) 2021 The Author(s)

Published by S. Karger AG, Basel

www.karger.com/crg

This article is licensed under the Creative Commons Attribution-NonCommercial 4.0 International License (CC BY-NC) (http://www.karger.com/Services/OpenAccessLicense). Usage and distribution for commercial purposes requires written permission.

\title{
Case and Review
}

\section{Collision Tumor of the Stomach}

\author{
Kimitoshi Kubo ${ }^{a}$ Ryo Takahashi ${ }^{b}$ Noriko Kimura ${ }^{c}$ Norishige Maiya ${ }^{a}$ \\ Soichiro Matsuda ${ }^{a}$ Momoko Tsuda ${ }^{a}$ Takeshi Mizushima ${ }^{a}$ \\ Masanori Ohara ${ }^{b}$ Mototsugu Kato ${ }^{a}$
}

aDepartment of Gastroenterology, National Hospital Organization Hakodate National Hospital, Hakodate, Japan; 'bepartment of Surgery, National Hospital Organization Hakodate National Hospital, Hakodate, Japan; 'Department of Pathology, National Hospital Organization Hakodate National Hospital, Hakodate, Japan

\section{Keywords \\ Collision tumor $\cdot$ Collision carcinoma $\cdot$ Stomach}

\begin{abstract}
Collison tumor of the stomach is rare, and its endoscopic and pathological features remain poorly described. A 70-year-old woman was referred to our hospital for examination and treatment of undifferentiated gastric cancer. Esophagogastroduodenoscopy revealed a whitish, superficial elevated lesion in contact with a reddish, superficial depressed lesion from the anterior wall of the gastric angle and antrum to the lesser curvature. Laparoscopic distal gastrectomy was performed for preoperative diagnosis of suspected early gastric cancer presenting as a differentiated and undifferentiated collision tumor, which led to the lesion being diagnosed as collision tumor, tub1-tub2+por1-sig, pT1a (M), ly0, v0, N0, stage IA. To our knowledge, this report represents a valuable addition to the collision tumor literature describing a rare case of preoperatively diagnosed collision tumor of the stomach.




\section{Case Reports in Gastroenterology}

\begin{tabular}{l|l}
\hline Case Rep Gastroenterol 2021;15:400-407 \\
\hline DOI: 10.1159/000514395 & $\begin{array}{l}\text { @ 2021 The Author(s). Published by S. Karger AG, Basel } \\
\text { www.karger.com/crg }\end{array}$ \\
\hline
\end{tabular}

Kubo et al.: Collision Tumor of the Stomach

\section{Introduction}

Collison tumor is defined as two types of independently occurring tumors that are in contact with each other or partially infiltrate and collide with each other [1]. Spagnolo and Heenan [2] reported the following diagnostic criteria: 1) the distribution of two different tissue types can be clearly distinguished, 2) each tissue type can be recognized even in the adjacent part, and 3) at the collision site, both components and their histological transition may be shown to exist. With regard to the stomach, only 20 cases have been reported in the last 20 years [3]. Collision tumor of the stomach is rare and its endoscopic and pathological features remain largely unclear. We herein report a case of collision tumor of the stomach that could be preoperatively diagnosed.

\section{Case Report/Case Presentation}

A 70-year-old woman visited a nearby clinic complaining of epigastric discomfort. Esophagogastroduodenoscopy (EGD) revealed a superficial depressed lesion in the lesser curvature of the gastric angle. An EGD biopsy revealed the lesion to be signet-ring cell carcinoma (sig). She was diagnosed with gastric cancer and referred to our hospital for further examination and treatment.

She had a history of cerebral infarction and hypertension. Serum H. pylori IgG antibody was positive $(38 \mathrm{U} / \mathrm{mL})$, suggesting that the patient was positive for $H$. pylori infection. EGD revealed a whitish, superficial elevated lesion in contact with a reddish, superficial depressed lesion from the anterior wall of the gastric angle and antrum to the lesser curvature on white light imaging (WLI) (Fig. 1a-f). Furthermore, an irregular microvascular (MV)/regular microsurface (MS) pattern was shown to be present within the demarcation line in a whitish, superficial elevated lesion on magnifying NBI (Fig. 2a, b). An irregular MV/irregular MS pattern was shown to be present within the demarcation line in a reddish, superficial depressed lesion on magnifying NBI (Fig. 2c, d). An EGD biopsy revealed tubular adenocarcinoma: well-differentiated type (tub1) - moderately differentiated type (tub2) and poorly differentiated adenocarcinoma (por) - sig, respectively. Laparoscopic distal gastrectomy with D1 lymph node dissection was performed for preoperative diagnosis of differentiated and undifferentiated early gastric cancer presenting as collision tumor.

Macroscopically, the resected specimen was an $18 \times 15 \mathrm{~cm}$ lesion with a negative margin. Histological examination revealed a whitish, superficial elevated lesion as tub1-tub2 and a reddish, superficial depressed lesion as por1-sig, with each shown to have negative margins. The differentiated (tub1-tub2) and undifferentiated (por1-sig) gastric cancers were shown to be distinctly localized on the resected specimen (Fig. 3a). Serial sections of the area showed clear boundaries and no histological transition where the two lesions collided (Fig. 3b). The gastric lesion in the patient was thus diagnosed as collision tumor, $45 \times 33 \mathrm{~mm}$, tub1tub2+por1-sig, pT1a (M), ly0, v0, N0, stage IA. Follow-up EGD examinations showed no signs of recurrence for 1 year.

\section{Karger's}




\section{Case Reports in Gastroenterology}

\begin{tabular}{l|l}
\hline Case Rep Gastroenterol 2021;15:400-407 \\
\hline DOI: 10.1159/000514395 & $\begin{array}{l}\text { @ 2021 The Author(s). Published by S. Karger AG, Basel } \\
\text { www.karger.com/crg }\end{array}$ \\
\hline
\end{tabular}

Kubo et al.: Collision Tumor of the Stomach

\section{Discussion/Conclusion}

Our case has two important clinical implications. First, gastric carcinomas of different histopathological types may present as a collision tumor. Collision tumor of the stomach is rare, and its endoscopic and pathological features remain poorly described in the literature.

Collision tumors of the stomach are usually found accidentally during pathological evaluation of surgically resected specimens and their components are reported to include carcinoma, carcinoid, gastrointestinal stromal tumor, sarcoma, myofibroblastic tumor, lymphoma, and teratoma. Of these, adenocarcinoma is shown to be the most common, and collision tumors of the stomach between different types of adenocarcinoma are reported to be the most common [3]. To date, twelve cases of collision tumors between gastric carcinomas have been reported (Table 1) [4-14] in 10 males and 2 females (mean age, 60.3 years), with the collision tumors between differentiated and undifferentiated adenocarcinomas being the most common (5 cases). Treatments implemented included total gastrectomy $(n=6)$, distal gastrectomy $(n=5)$, and endoscopic submucosal dissection $(n=1)$. Of these cases, only one case was preoperatively diagnosed as a collision tumor consisting of type 4 and 1 gastric cancer lesions [6]. In the present case, a clear boundary was shown between the differentiated and undifferentiated adenocarcinomas on WLI, and the tumor was amenable to endoscopic diagnosis with magnifying NBI. In addition, the endoscopic and pathological boundaries were shown to be consistent by mapping these areas with those of the resected specimen; thus, our case may be of particular interest in that it was preoperatively diagnosed.

The second important issue that emerged in our case was that the collision tumor had been derived from the same atrophic mucosa associated with $H$. pylori-associated chronic gastritis. According to Strofilas et al. [15], carcinogens, such as H. pylori, Epstein-Barr virus, and certain chemicals, induce synchronous and close development of different neoplasms that finally collide. In our case, the patient was shown to be positive for serum IgG antibody to $H$. pylori, which led us to assume that the differentiated and undifferentiated early gastric cancer lesions developed separately and collided to form a collision tumor against a background of H. pylori-associated chronic gastritis.

In conclusion, gastric carcinomas of different histopathological types may present as collision tumors. In the diagnosis of gastric cancer, therefore, not only endoscopic diagnosis by WLI and magnifying NBI but accurate diagnosis by biopsy should be implemented with the potential presence of collision tumor in mind.

\section{Statement of Ethics}

Written informed consent was obtained from the patient for publication of this case report and any accompanying images.

\section{Karger'=}


Case Reports in
Gastroenterology

Case Rep Gastroenterol 2021;15:400-407

DOI: $10.1159 / 000514395$

(C) 2021 The Author(s). Published by S. Karger AG, Basel www.karger.com/crg

Kubo et al.: Collision Tumor of the Stomach

\section{Conflict of Interest Statement}

The authors have no conflicts of interest to disclose in association with this study.

\section{Funding Sources}

The authors received no funding for this research.

\section{Author Contributions}

K.K., R.T., N.K., N.M., S.M., M.T., T.M., M.O., and M.K. contributed equally to the study as well as to the preparation of the manuscript for publication.

\section{References}

1 Meyer R. Beitrag zur Verständigung über die Namengebung in der Geschwulstlehre. Zentralbl Allg Pathol. 1919;30:291-6.

2 Spagnolo DV, Heenan PJ. Collision carcinoma at the esophagogastric junction: report of two cases. Cancer. 1980 Dec;46(12):2702-8.

3 Schizas D, Katsaros I, Michalinos A, Damaskos C, Garmpis N, Ntomi V, et al. Collision tumors of the gastrointestinal tract: a systematic review of the literature. Anticancer Res. 2018 Nov;38(11):6047-57.

4 Nambu S, Tanaka M, Shibuya T, Fujikura S, Sasaki H, Hirokawa S, et al. A case study of colliding gastric cancer [in Japanese]. Gastroenterol Endosc. 1984;26:1118-25.

5 Aoyagi K, Hashimoto K, Kohfuji K, Tanaka T, Kodama I, Yano S, et al. Two cases of colliding carcinoma of the stomach [in Japanese]. Jpn J Gastroenterol Surg. 1992;25(8):2152-6.

6 Kunisaki C, Kobayashi S, Kido Y, Imai S, Harada H, Moriwaki Y, et al. A case of collision carcinoma of the stomach [in Japanese]. Jpn J Cancer Clin. 1996;42:1141-6.

7 Kanetaka K, Hamada T, Kohara N, Amano M, Kawai K. Interesting features of p53 immunostaining in a case of gastric combination carcinoma [in Japanese]. Jpn J Cancer Clin. 1999;45:43-7.

8 Igari K, Toukairin Y, Kumagai Y, Iida M, Yamazaki S. A case of collision carcinoma of the stomach [in Japanese]. Rinsho Zassi Geka. 2008;70:1007-10.

9 Jang KY, Moon WS, Lee H, Kim CY, Park HS. Gastric collision tumor of large cell neuroendocrine carcinoma and adenocarcinoma - a case report. Pathol Res Pract. 2010 Jun;206(6):387-90.

10 Lee HH, Jung CK, Jung ES, Song KY, Jeon HM, Park CH. Mixed exocrine and endocrine carcinoma in the stomach: a case report. J Gastric Cancer. 2011 Jun;11(2):122-5.

11 Erkol B, Tilki M, Comunoğlu N, Öven Ustaalıŏlu BB, Aker F, Sürmelioğlu A, et al. Neuroendocrine/squamous gastric collision tumor: A rare entity. Turk J Gastroenterol. 2014 Dec;25 Suppl 1:282-3.

12 Payet E, Pilco PI, Montes J, Cordero-Morales A, Savitzky MJ, Stenning-Persivale K. Collision tumour of largecell neuroendocrine carcinoma and adenocarcinoma in the stomach: A case report. Ecancermedicalscience. 2016 Jan;10:616.

13 Takahashi K, Fujiya M, Ichihara S, Moriichi K, Okumura T. Inverted gastric adenocarcinoma of fundic gland mucosa type colliding with well differentiated adenocarcinoma: A case report. Medicine (Baltimore). 2017 Jun;96(23):e7080.

14 Fukuda S, Fujiwara Y, Wakasa T, Inoue K, Kitani K, Ishikawa H, et al. Collision tumor of choriocarcinoma and small cell carcinoma of the stomach: A case report. Int J Surg Case Rep. 2017;37:216-20.

15 Strofilas A, Dalianoudis IG, Lagoudianakis EE, Genetzakis M, Tsekouras D, Chrysikos J, et al. Collision tumour of the stomach with a cancer to cancer metastasis: a case report. Cases J. 2008 Jul;1(1):63.

\section{Karger'=}




\section{Case Reports in Gastroenterology}
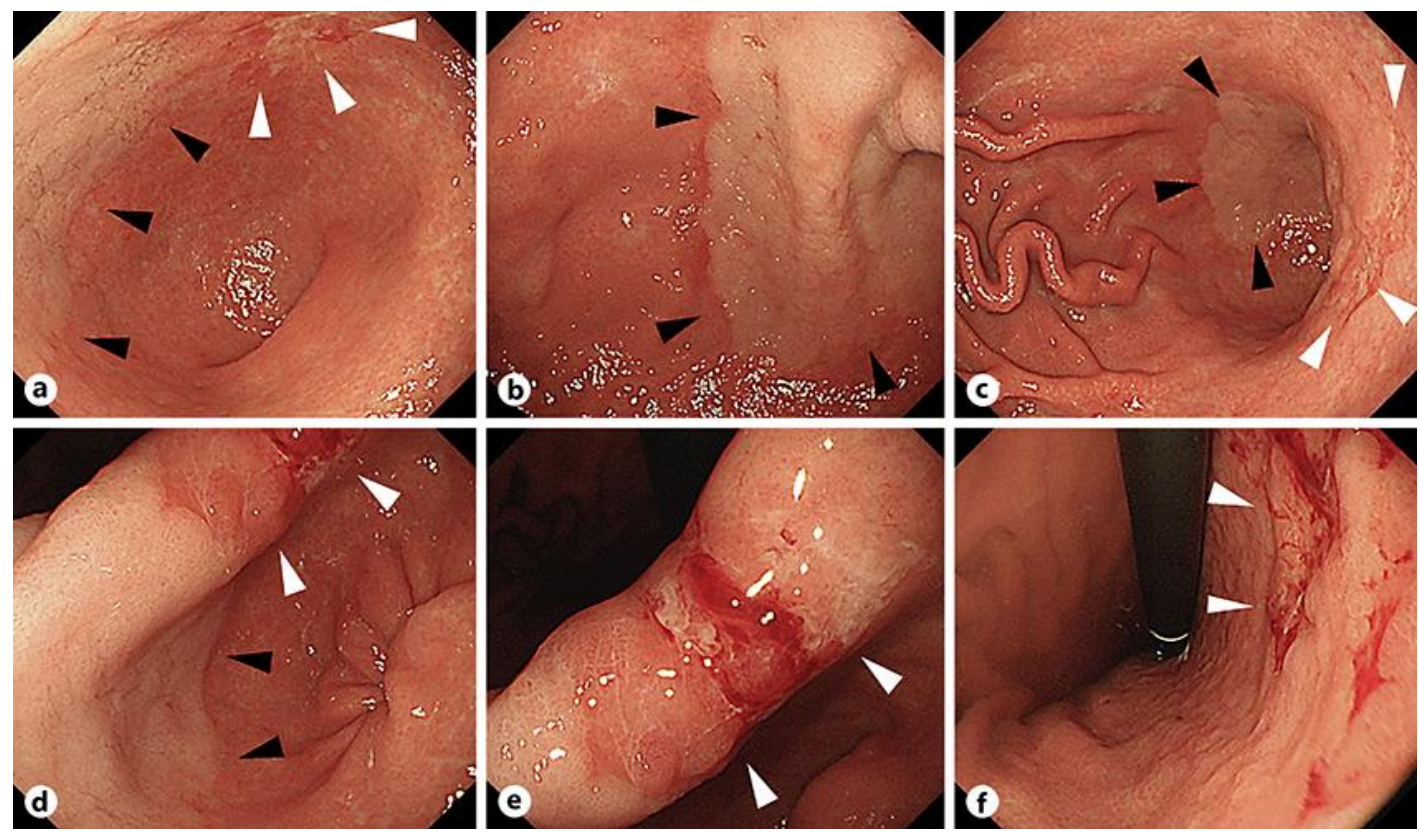

Fig. 1. Esophagogastroduodenoscopy. A whitish, superficial elevated lesion ( $\mathbf{\Lambda})$ in contact with a reddish, superficial depressed lesion $(\Delta)$ from the anterior wall of the gastric angle and antrum to the lesser curvature on white light imaging (WLI) (a-f). 


\section{Case Reports in Gastroenterology}

Case Rep Gastroenterol 2021;15:400-407
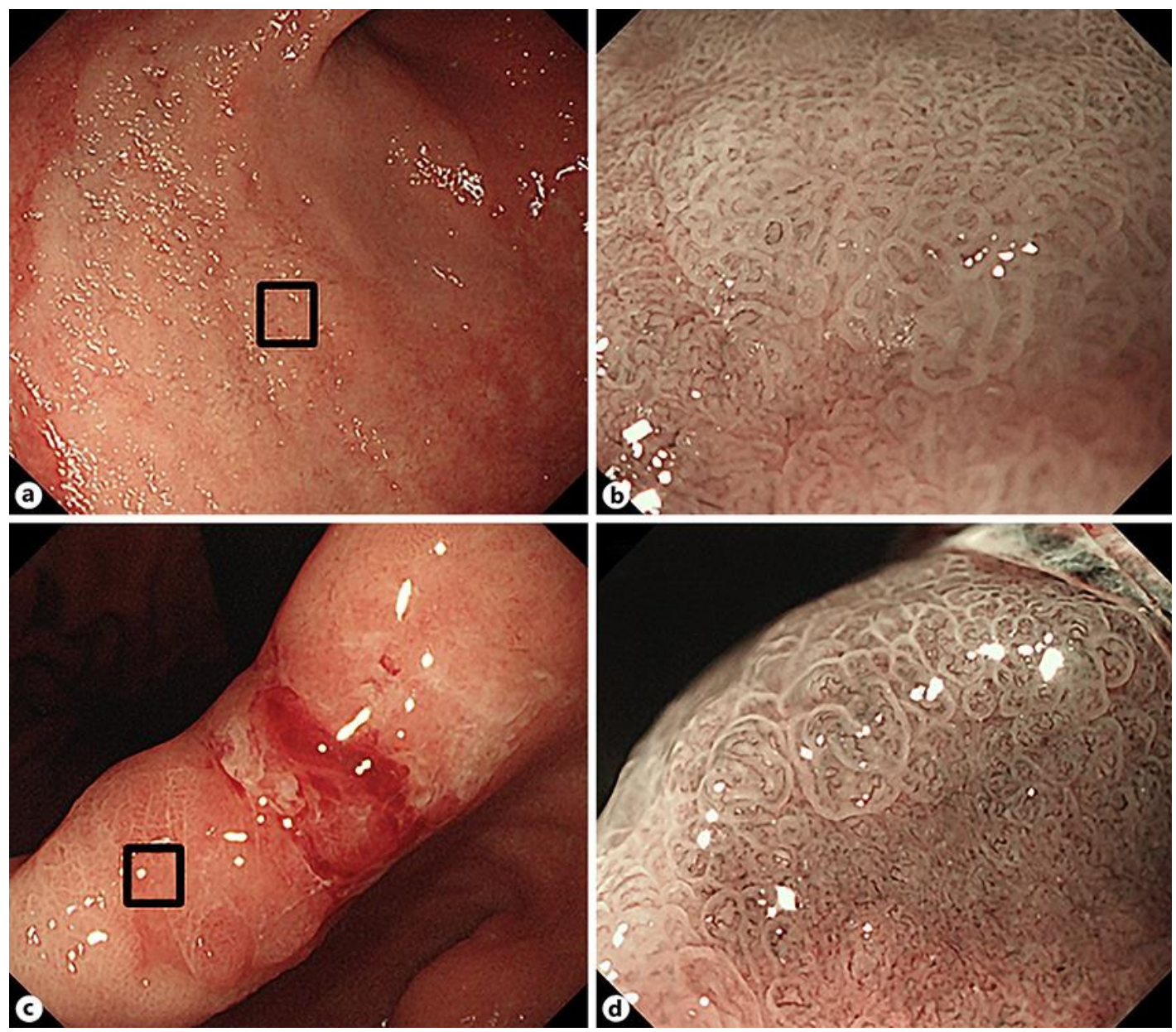

Fig. 2. Magnifying NBI. An irregular microvascular (MV)/regular microsurface (MS) pattern was shown to be present within the demarcation line in a whitish, superficial elevated lesion (a, b). An irregular MV/irregular MS pattern was shown to be present within the demarcation line in a reddish, superficial depressed lesion (c, d). 


\section{Case Reports in Gastroenterology}
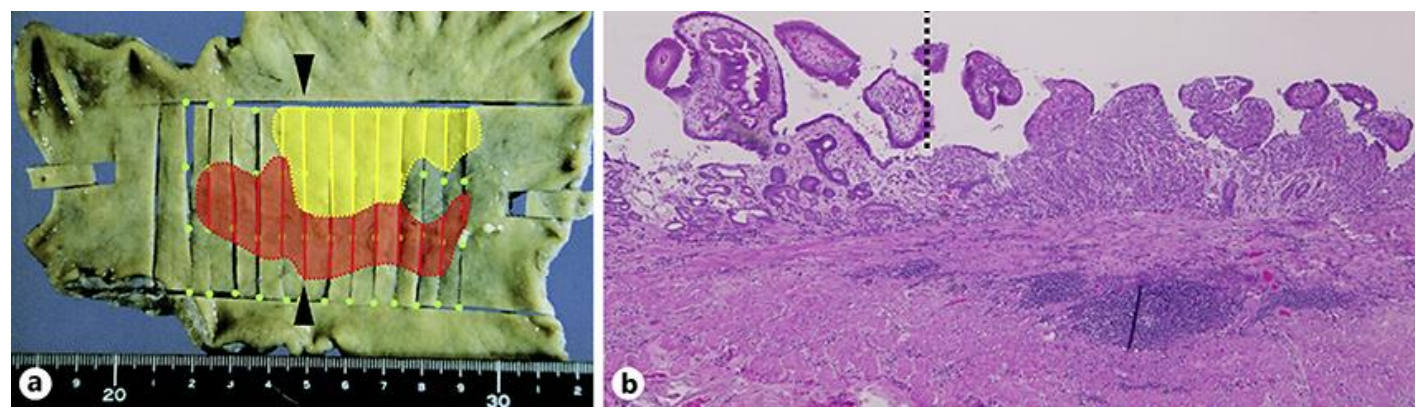

Fig. 3. Specimen mapping and histopathologic examination. The differentiated (tub1-tub2) and undifferentiated (por1-sig) gastric cancers were distinctly localized (shown in yellow and red, respectively) (a). Serial sections of the area showed clear boundaries and no histological transition where the two lesions collided (the left and right sides of the dotted line representing tub1 and por1, respectively) (magnification, $\times 20$ ) (b). 


\section{Case Reports in Gastroenterology}

\begin{tabular}{l|l}
\hline Case Rep Gastroenterol 2021;15:400-407 \\
\hline DOI: 10.1159/000514395 & $\begin{array}{l}\text { (c) } 2021 \text { The Author(s). Published by S. Karger AG, Basel } \\
\text { www.karger.com/crg }\end{array}$ \\
\hline
\end{tabular}

Kubo et al:: Collision Tumor of the Stomach

Table 1. Cases reported to date of collision tumors between gastric cancers

\begin{tabular}{|c|c|c|c|c|c|c|c|c|c|}
\hline No. & Ref. & Year & $\begin{array}{l}\text { Age, } \\
\text { years }\end{array}$ & Sex & $\begin{array}{l}\text { Loca- } \\
\text { tion }\end{array}$ & $\begin{array}{l}\text { Macroscopic } \\
\text { type }\end{array}$ & Pathology 1 & Pathology 2 & Treatment \\
\hline 1 & {$[4]$} & 1984 & 71 & $\mathrm{~F}$ & $\mathrm{~L}$ & Type 2 & Squamous cell carcinoma & Papillary adenocarcinoma & Total gastrectomy \\
\hline 2 & [5] & 1992 & 72 & M & M & Types 2/0-IIa & $\begin{array}{l}\text { Well-differentiated } \\
\text { adenocarcinoma }\end{array}$ & $\begin{array}{l}\text { Poorly differentiated } \\
\text { adenocarcinoma }\end{array}$ & Total gastrectomy \\
\hline 3 & [5] & 1992 & 52 & M & $\mathrm{L}$ & Types 0-IIa/0-IIc & $\begin{array}{l}\text { Well differentiated } \\
\text { adenocarcinoma }\end{array}$ & $\begin{array}{l}\text { Poorly differentiated } \\
\text { adenocarcinoma }\end{array}$ & Distal gastrectomy \\
\hline 4 & {$[6]$} & 1996 & 68 & M & UML & Types 4/1 & Tubular adenocarcinoma & $\begin{array}{l}\text { Poorly differentiated } \\
\text { adenocarcinoma }\end{array}$ & Total gastrectomy \\
\hline 5 & [7] & 1999 & 58 & M & ML & Type 2 & $\begin{array}{l}\text { Well-differentiated } \\
\text { adenocarcinoma }\end{array}$ & $\begin{array}{l}\text { Poorly differentiated } \\
\text { adenocarcinoma }\end{array}$ & Distal gastrectomy \\
\hline 6 & {$[8]$} & 2008 & 83 & $\mathrm{~F}$ & $\mathrm{~L}$ & Type 2 & $\begin{array}{l}\text { Well-differentiated } \\
\text { adenocarcinoma }\end{array}$ & $\begin{array}{l}\text { Poorly differentiated } \\
\text { adenocarcinoma }\end{array}$ & Distal gastrectomy \\
\hline 7 & [9] & 2010 & 50 & M & $\mathrm{L}$ & Type 2 & Large cell carcinoma & $\begin{array}{l}\text { Well-differentiated } \\
\text { adenocarcinoma }\end{array}$ & Distal gastrectomy \\
\hline 8 & {$[10]$} & 2011 & 62 & M & M & Type 1 & $\begin{array}{l}\text { Small cell neuroendocrine } \\
\text { carcinoma }\end{array}$ & $\begin{array}{l}\text { Poorly differentiated } \\
\text { adenocarcinoma }\end{array}$ & Distal gastrectomy \\
\hline 9 & {$[11]$} & 2014 & 45 & M & $\mathrm{U}$ & $(-)$ & Squamous cell carcinoma & Neuroendocrine carcinoma & Total gastrectomy \\
\hline 10 & {$[12]$} & 2016 & 71 & M & UM & Type 3 & $\begin{array}{l}\text { Large cell neuroendocrine } \\
\text { carcinoma }\end{array}$ & Tubular adenocarcinoma & Total gastrectomy \\
\hline 11 & {$[13]$} & 2016 & 87 & M & M & Types 0-I/0-IIc & $\begin{array}{l}\text { Adenocarcinoma of fundic } \\
\text { gland type }\end{array}$ & $\begin{array}{l}\text { Well-differentiated } \\
\text { adenocarcinoma }\end{array}$ & ESD \\
\hline 12 & [14] & 2017 & 84 & M & U & Type 1 & Choriocarcinoma & Small cell carcinoma & Total gastrectomy \\
\hline 13 & $\begin{array}{l}\text { Our } \\
\text { case }\end{array}$ & 2020 & 70 & $\mathrm{~F}$ & ML & Types 0-IIa/0-IIc & $\begin{array}{l}\text { Well-differentiated and } \\
\text { moderately differentiated } \\
\text { adenocarcinoma }\end{array}$ & $\begin{array}{l}\text { Poorly differentiated ade- } \\
\text { nocarcinoma and signet- } \\
\text { ring cell carcinoma }\end{array}$ & Distal gastrectomy \\
\hline
\end{tabular}

ESD, endoscopic submucosal dissection. 